\title{
Perception and Attitudes of Residents Towards Green Spaces in Croatia - an Exploratory Study
}

\author{
Ana Marija Marin ${ }^{1, *}$, Martina Kičić ${ }^{1, *}$, Dijana Vuletić ${ }^{1}$, Silvija Krajter Ostoić ${ }^{1}$
}

(1) Croatian Forest Research Institute, Department for International Scientific Cooperation in Southeast Europe - EFISEE, Cvjetno naselje 41, HR-10450 Jastrebarsko, Croatia

*Correspondence: e-mail: anamari@sumins.hr, martinak@sumins.hr

\begin{abstract}
Citation: Marin AM, Kičić M, Vuletić D, Krajter Ostoić S, 2021. Perception and Attitudes of Residents Towards Green Spaces in Croatia - an Exploratory Study. South-east Eur for 12(2): 123-134. https://doi.org/10.15177/seefor.21-12. Received: 6 Oct 2021; Revised: 15 Nov 2021; Accepted: 16 Nov 2021; Published online: 2 Dec 2021
\end{abstract}

\begin{abstract}
Green spaces are important parts of urban infrastructure. COVID-19 pandemic and lockdown periods around the world have confirmed benefits that people derive from using green spaces for their physical and mental health. Green spaces need to meet the needs of users so that people can use them and benefit over time. It is important to consider users' perceptions and attitudes. User input proves beneficial in improving management practices. We investigated the differences in attitudes and perceptions of respondents from different large settlements in Croatia towards green spaces. Data on the use and perception of green spaces were collected in the first lockdown period in Europe and processed the part of the questionnaire on attitudes and perceptions towards green spaces. People have similar, mostly positive perceptions of green spaces regardless of the size of the settlement. Differences were found in the perception of disadvantages and needs related to the management of green spaces. This is the first study of the attitudes and perceptions on a large spatial scale in Croatia, so the results are exploratory and important. This study contributes to research on the social aspects of green spaces by investigating the influence of environmental context on perceptions and attitudes.
\end{abstract}

Keywords: perception; attitudes; environment; settlements; questionnaire; cultural ecosystem services; ecosystem services

\section{INTRODUCTION}

Green spaces are one of the most important components of infrastructure in cities. The benefits they provide to citizens are numerous and are often referred to as urban ecosystem services to highlight the benefits they provide to the urban environment (Haase et al. 2014). The recent COVID-19 pandemic has shown the importance of urban green spaces for citizens and their mental health, especially during lockdown periods (Poortinga et al. 2021, Pouso et al. 2021), highlighting the importance of green spaces for residents around the world (Derks et al. 2020, Morse et al. 2020, Ugolini et al. 2020, Venter et al. 2020). Therefore, green spaces have become one of the most important components of urban infrastructure in times of crisis (Kleinschroth and Kowarik 2020).

Therefore, it is important to manage green spaces in a way that they continue to provide ecosystem services to urban residents. To plan and manage high quality and appropriate green spaces, it is important to understand their users, which requires conducting empirical social studies (Lo and Jim 2012). In addition, many countries are experiencing rapid urbanization, with more and more people living in cities. The process of urbanization is characterized by pressure on vacant land and its subsequent conversion into construction areas for new housing. This process is particularly evident in cities undergoing transition, such as postsocialist cities. In these cities, many of which can be found in Eastern Europe, there is a significant process of land-use change leading to the loss of green spaces. Furthermore, in such cities, there is often a lack of public participation in decision-making regarding green spaces. This is often because citizens are not interested in participating and have more pressing issues, such as meeting basic household needs, or lack of trust in local authorities or limited opportunities to participate in such issues (Kronenberg et al. 2020). However, public participation in green space planning and management, when perceived as democratic and fair, contributes to 
improving the quality of environmental decisions (Reed 2008).

Research on public perceptions of green spaces can tell us a lot about how people experience green spaces. Therefore, this research on public perceptions of and attitudes towards green spaces use quantitative, qualitative or mixed methods. Quantitative methods usually involve a survey of a sample of citizens looking at, for example, perceptions of parks (Buchel and Frantzeskaki 2015), urban forests (Larondelle and Haase 2017, Kičić et al. 2020), brownfield sites (Mathey et al. 2018) and visual and auditory perceptions of green spaces (Gunnarsson et al. 2017). Qualitative methods offer an in-depth exploration of perceptions that provide insight into experiences and motivations for using urban parks (Gunnarsson et al. 2017) or perceptions of the cultural ecosystem services provided by different types of urban green space (Maraja et al. 2016, Ostoić et al. 2020b). While there are studies that directly examine the attitudes of different user groups towards green spaces (Baur et al. 2013), there are also studies that understand attitudes and perceptions as synonyms rather than distinct concepts (Mathey et al. 2018). Despite the differences in definitions, these studies examine public opinion on a variety of issues related to urban green spaces. The attitudes and preferences people express towards green spaces are diverse and influenced by numerous factors, and at the same time, the way people use these attitudes is complex (Swanwick 2009). Moreover, the same study emphasizes that attitudes and perceptions are usually location-specific and can only be fully understood in the context of the environment. Other research shows that where people live (e.g., urban or rural areas) can have an impact on their perceptions of a particular environmental issue, and that experiences of nature in different environments influence attitudes and actions toward the environment (Berenguer et al. 2005).

Studies on the perception of urban green spaces are not yet very common in Croatia and are usually conducted in Zagreb, the capital and the largest city in the country (Krajter Ostoić et al. 2020a). Nevertheless, research on the perception of cultural ecosystem services of urban green spaces in Zagreb has shown that people perceive and use/experience different cultural ecosystem services in different types of tree-covered urban green spaces (Ostoić et al. 2020). Besides, there are few studies on the perception and satisfaction of urban green spaces even in southeastern Europe. A recent regional study on this topic was conducted among residents of larger cities in the region (Krajter Ostoić et al. 2017). The study showed that residents of major cities in southeast Europe consider urban forests and green spaces important, but also that they need more such spaces. Moreover, for the respondents in the study, management practices were more important than physical aspects of green spaces, such as size and connectivity. For the residents of Zagreb, vandalism, trash cans, litter, other users and benches were the most frequently perceived problems. The main objective of this article is to investigate the perception and attitude of Croatian citizens towards green spaces. In particular, it will be analysed whether there are differences in attitudes and perceptions of green spaces between people living in large and small settlements.
It is hypothesised that there is a difference in perception and attitude based on the size of the place of residence, considering the population size.

\section{MATERIALS AND METHODS}

\section{Study Area}

The Republic of Croatia is a relatively small country in southeastern Europe. It is $56,594 \mathrm{~km}^{2}$ in size and has about 4.3 million inhabitants. Its territory is divided into 21 regional units with a total of 128 cities. Of the total number of cities, only four have a population of 100,000 or more. Zagreb, with about 790,000 inhabitants, is the largest city and also a regional unit. About $75 \%$ of all inhabitants in Croatia live in urban areas (Statistical Yearbook of the Republic of Croatia 2018).

\section{The Data Collection}

Data for this article were collected using an online questionnaire. The questionnaire was developed in early March 2020 by researchers from the Institute of Bioeconomics of the Italian National Research Council in collaboration with the University of Bari in Italy and BenGurion University of the Negev in Israel. The questionnaire was developed to investigate the use, attitudes and feelings towards urban green spaces during the first closure period in Europe due to the spread of the SARS-CoV-2 virus. The questionnaire was the instrument for a broader international exploratory study conducted simultaneously in Chile, Croatia, Israel, Italy, Lithuania, Slovenia and Spain. The original questionnaire was translated into English and then into local languages before being distributed, including Croatian.

The authors distributed the link to the questionnaire to the general public through their personal and professional networks via email and social media (Facebook, WhatsApp and Messenger). Respondents were kindly asked to share the link with their contacts. Access to the questionnaire in Croatia was granted in the period between 17 April and 4 May 2020. The criteria for respondents were that they were over 18 years old and lived in Croatia during the lockdown period.

\section{Survey Questionnaire}

The questionnaire was designed as an online survey at Google Forms. It consisted of nine sections of 30 to 45 questions. Some questions were divided into questions about visiting behaviour before and during the closure period. The questionnaire was semi-structured and consisted of questions with predefined answers and open-ended questions. In the introductory section of the questionnaire, participants were informed about the purpose of the research and their formal consent to participate and consent to the handling of personal data was obtained. Participation in the survey was voluntary, with no incentives offered, and participants had the option to opt-out of the questionnaire at any time.

The questionnaire collected data on the use of green spaces before the lockdown, the use during the lockdown, reflections on the perception and value of green spaces 
for the respondents, satisfaction with certain services of the green spaces they use most often and suggestions for green spaces in their places of residence in the open-ended question, and, finally, the socio-demographic data of the respondents. Since the focus of this article is to explore the perceptions and attitudes of residents of differently sized settlements, only the results relevant to the main topic are presented here. Therefore, information and results related to the use of green spaces before and during the lockdown period are not included.

\section{Data Sample and Analysis}

The sample was not randomly drawn and included 463 respondents. Before the analyses began, three respondents from abroad were excluded from further analyses, so that the total number of respondents whose answers were included in the analyses was 460 .

The sample of 460 respondents was used to analyse questions relating to attitudes towards the benefits of green spaces, management and perceived disadvantages, as well as levels of agreement with the various general aspects of green spaces.

Respondents were asked on a 7-point Likert scale (from 1 - "strongly disagree" to 7 - "strongly agree") to express their general level of agreement with statements about the benefits of green spaces, their management and perceived disadvantages. The dataset was split into two subgroups based on place of residence: respondents from larger towns who answered that they lived in a large city with a population of more than $100,000(\mathrm{~N}=340)$, and respondents from smaller towns who answered that they lived in small towns with a population of less than 100,000 and rural areas $(\mathrm{N}=120)$. The combination of people living in small towns and villages is possible because in Croatia the local context of the two environments is similar and different from large urban environments.

In the analyses, the percentage of respondents' agreement with each statement was first plotted on a common graph to visually examine the distribution of agreement levels in each group of respondents. The topic was then further analysed using statistics. The data were examined for possible differences in the level of agreement with the statements on the 7-point Likert scale using the Wilcoxon-Mann-Whitney U-test, a nonparametric test that does not assume a normal distribution of the data, with a significance level of $p<0.05$.

To further corroborate the initial results of the Likert scale data, responses to questions about the management of green spaces, the personal importance of public/private green spaces, and what respondents would improve about the green spaces they know or frequently use were also analysed. All these questions had predefined responses that respondents could select. Contingency tables with the frequencies of the selected responses concerning the subdivision into two categories based on the indicated place of residence were created. These tables were then tested for independence using the chi-square test with a significance level of $p<0.05$

Differences in the level of satisfaction with various aspects of known or frequent green space were analysed using the chi-square test for the frequency of responses given for each aspect between the two groups at a significance level of $p<0.05$.

The responses to the open-ended question about considerations and suggestions for green spaces in their respective places of residence were coded and the codes were presented with the frequency and description of each code.

The socio-demographic data of the respondents were analysed using descriptive statistics on the sample of 460 respondents. The analyses were performed using $R$ v3.6.2 software. For the Likert scale data, the "Likert" package was used.

\section{RESULTS}

\section{Sociodemographic Features of the Respondents}

About three quarters of the respondents were women (Table 1). More than half of all respondents were between 30 and 49 years old. The fewest respondents were in the age group below 20 years (1\%) and the age group between 60 and 79 years (7\%). More than three quarters of the respondents reported having a university degree. About the same proportion of the respondents were employed either in public or private companies or worked as freelancers. Almost three quarters of the respondents lived in municipalities with more than 100,000 inhabitants.

\section{Attitudes Toward Green Spaces and Management}

As mentioned earlier, before analysis, respondents were divided into two categories based on the number of residents in their locality. The first category includes respondents from small towns and rural areas (Small Settlements) with 120 respondents, and the second category (Large Settlements) includes respondents from large cities, with 360 respondents in the sample. The first group of statements were related to attitudes towards the benefits that green spaces provide to residents, such as improving public health and social cohesion, as well as statements stating that access to green spaces is a primary right for all citizens and that everyone should have access to a green space within 300 meters of their home. People had overwhelmingly positive attitudes towards all statements, regardless of where they lived (Figure 1). There were no statistically significant differences in agreement between residents of the larger and smaller settlements. Therefore it could be concluded that there are differences in the environment, but no differences in attitudes towards the benefits of green space between the two groups of respondents.

The second group of statements were related to the management of green spaces and possible disadvantages. The respondents showed high agreement with the statement that new buildings should be compensated with new green spaces and slightly lower agreement with the provision of more funds for green space management. For other statements, the majority of respondents indicated disagreement that trees should be removed from streets, that they cause practical problems, or that they pose a danger to people (Figure 2). Statistically significant differences between residents of larger and smaller settlements were found for only two statements. These are "The presence of 
Table 1. Sociodemographic characteristics of the respondents $(N=460)$.

\begin{tabular}{|c|c|c|}
\hline Variable & Category & Percentage of respondents \\
\hline & Male & 23.7 \\
\hline \multirow[t]{5}{*}{ Gender } & Female & 76.1 \\
\hline & I do not want to state & 0.2 \\
\hline & Less than 20 years old & 0.9 \\
\hline & Between 20 and 29 & 16.5 \\
\hline & Between 30 and 39 & 28.3 \\
\hline \multirow[t]{6}{*}{ Age } & Between 40 and 49 & 27.2 \\
\hline & Between 50 and 59 & 20.4 \\
\hline & Between 60 and 69 & 5.2 \\
\hline & Between 70 and 79 & 1.5 \\
\hline & Primary & 0.4 \\
\hline & High school & 23.0 \\
\hline \multirow{4}{*}{ Education } & University/college degree & 61.1 \\
\hline & Post-graduate degree & 15.4 \\
\hline & Employee (public / private) & 67.6 \\
\hline & Freelance, private business & 10.9 \\
\hline \multirow[t]{5}{*}{ Employment } & Retired & 5.7 \\
\hline & Unemployed & 5.9 \\
\hline & Student & 8.7 \\
\hline & Homemaker & 1.3 \\
\hline & Big town/city (more than 100.000 inhabitants) & 73.9 \\
\hline \multirow[t]{2}{*}{ Place of residence } & Small town (less than 100.000 inhabitants) & 19.1 \\
\hline & Village/rural area & 7.0 \\
\hline
\end{tabular}

green space is a problem because it increases housing costs" $(\mathrm{W}=18306, \mathrm{p}=0.0431)$ and "Trees along roads pose a risk to people" ( $W=17779, p=0.0085)$. Interestingly, the residents of larger settlements were more likely to disagree with both statements than the residents of smaller settlements.

Series of questions with predefined answers from the questionnaire, dealing with different aspects of green spaces and their management, to complement the results of the Likert scale questions were used. These questions allowed the respondents to select the answers they considered important. The frequency of responses between two groups of respondents was examined for possible differences. First, the respondents were asked which area they would prioritize in public administration. The majority of respondents in both groups indicated that they would prioritize "waste management", while "green management" was ranked second in both groups. The chi-square test showed no difference in the frequency of the selected responses between the groups (Table 2).

Moreover, the respondents in both groups found public gardens more important than private ones (Table 2). The chi-square test showed a statistically significant difference between the two groups, indicating that responses were determined by place of residence, with individuals from larger towns finding public gardens much more important than private gardens.

The final question analyzed was about the aspects that the respondents would like to improve in green spaces that 
How much do you agree with the following statements?

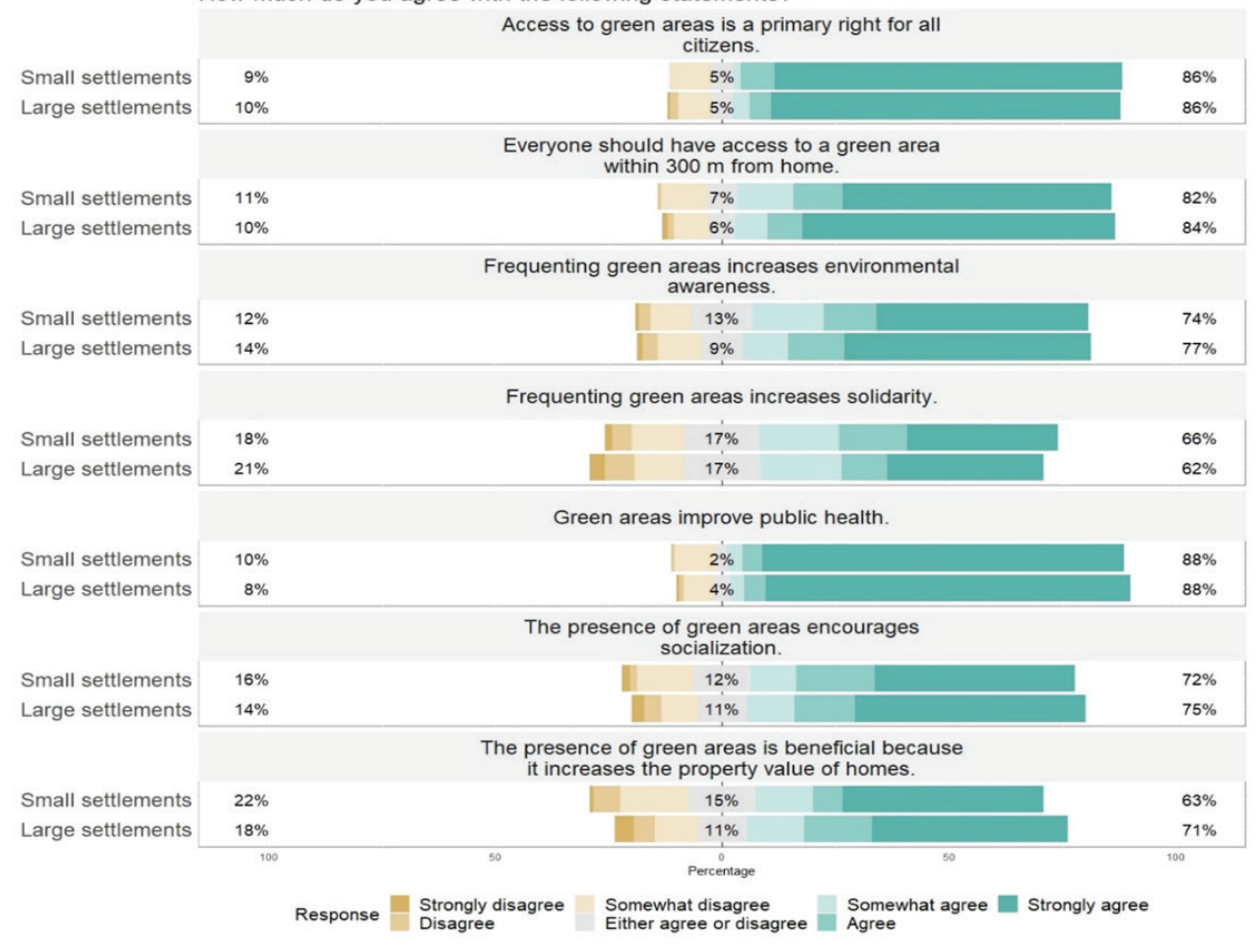

Figure 1. Attitudes toward green space benefits $(N=460)$.

How much do you agree with the following statements?

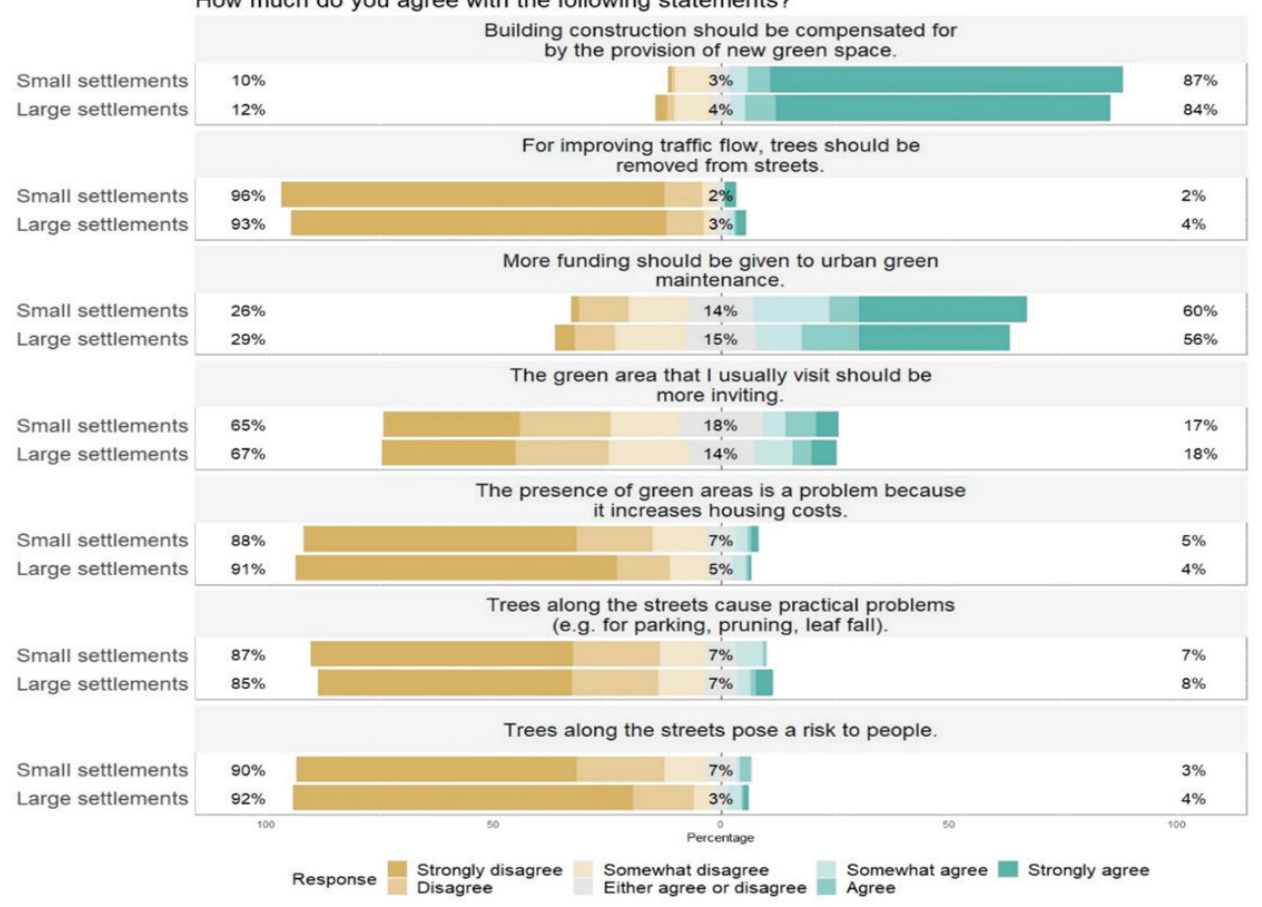

Figure 2. Attitudes toward green space management and perception of potential disservices ( $N=460)$. 
Table 2. Frequencies of answers to questions regarding green spaces in the place of residence.

\begin{tabular}{|c|c|c|c|c|}
\hline \multirow{2}{*}{ Question } & \multirow{2}{*}{ Answers } & \multicolumn{2}{|c|}{ Frequencies } & \multirow{2}{*}{$\mathrm{X}^{2}$} \\
\hline & & Large communities & Small communities & \\
\hline \multirow{4}{*}{$\begin{array}{l}\text { In the public } \\
\text { management of the } \\
\text { town, which sector } \\
\text { would you prioritize? }\end{array}$} & Green management & 90 & 27 & \multirow{4}{*}{$\begin{array}{l}X^{2}=1,5914 \\
p=0.6614\end{array}$} \\
\hline & Public transportation & 51 & 16 & \\
\hline & Street maintenance & 16 & 8 & \\
\hline & Waste management & 183 & 69 & \\
\hline \multirow{2}{*}{$\begin{array}{l}\text { What do you consider } \\
\text { more important? }\end{array}$} & Private garden & 77 & 53 & \multirow{2}{*}{$\begin{array}{l}X^{2}=19,212 \\
p=0.0001\end{array}$} \\
\hline & Public garden & 263 & 67 & \\
\hline \multirow{8}{*}{$\begin{array}{l}\text { What would you } \\
\text { improve in the green } \\
\text { area that you know or } \\
\text { frequent? }\end{array}$} & Aesthetic appearance & 22 & 19 & \multirow{8}{*}{$\begin{array}{c}X^{2}=17,763 \\
p=0.01\end{array}$} \\
\hline & Areas for sports and recreation & 7 & 27 & \\
\hline & Elements for relaxation & 90 & 40 & \\
\hline & Level of noise pollution & 4 & 7 & \\
\hline & Microclimate & 62 & 17 & \\
\hline & Natural value & 131 & 33 & \\
\hline & Visibility with open areas & 11 & 4 & \\
\hline & Waste collection/cleanliness & 134 & 52 & \\
\hline
\end{tabular}

they use frequently or know well. Again, the respondents had a range of preset answers from which they could choose two, with the option to give an open response. For this analysis, the frequencies of the predefined responses that the respondents chose were used. The frequency table contained 564 entries from the respondents from large settlements and 199 entries from the respondents from smaller settlements. Respondents from larger settlements most frequently selected "Waste collection/cleanliness" and "Natural value", while "Elements for relaxation" ranked third in terms of frequency. In addition, respondents from smaller settlements preferred "Waste collection/Cleanliness" and "Elements for relaxation" while "Natural value" ranked third. Respondents from larger communities were least likely to want to improve the "Level of noise pollution", "Areas for sports and recreation" and "Visibility" of the place they know or visit. Even in smaller communities, "Level of noise pollution" and "Visibility" are the elements the respondents are most satisfied with, while "Aesthetic appearance" comes in third. The chi-square test showed that there are differences in the frequency of responses given between two groups of respondents. This means that the respondents indicate a different need for improvement in green spaces depending on where they live.

\section{Satisfaction with Green Spaces}

After the statements on the benefits of green spaces, attitudes towards management and perceptions of potential disadvantages, the questionnaire addressed the perceptions of green spaces that respondents know or visit. Respondents indicated their satisfaction with several predefined elements/characteristics of green spaces on a Likert scale ranging from 'Not at all' to 'Very much', with the option to answer 'I am not interested'. More than onethird of the respondents were "Rather satisfied" with the predefined elements of the green space of their choice. Onethird of the respondents were "Not at all" or "Little satisfied" (Figure 3). Both groups of respondents were least satisfied with "Equipment for relaxing," "Presence of recreational facilities," and "Presence of wild animals", while they were slightly more satisfied with "Accessibility," "Makes hot days more mild" and "Natural value." In addition, the frequencies of responses to each green space aspect were tested for differences between the respondents from large and small settlements using the chi-square test. A significant difference between the frequencies was only found for "Equipment for relaxing (e.g. picnic tables/benches)" ( $\chi 2=$ $14.344, p=0.00627)$. This means that the respondents from small settlements were significantly less satisfied with the amenities of their green spaces than the respondents from large settlements.

\section{Reflections on Green Spaces - Answers to an Open- Ended Question}

In the open-ended question the respondents were asked to share their thoughts and suggestions regarding 
green spaces in their locality. The responses were coded and the codes and their descriptions are presented below. Responses from 460 people were coded, and a total of 554 codes were assigned, so some of the responses covered multiple topics. Of the total number of responses analysed, 133 people did not make any suggestions (27\% of them indicated that they were satisfied with the current state, and $73 \%$ indicated that they had no opinion or did not write anything). In the first round of coding, general categories of codes were assigned to each response based on the themes mentioned, while in the second round of coding these codes were further developed to obtain more detailed information. Most respondents' suggestions were related to urban planning ( $25 \%$ of all assigned codes), followed by green space design (19\%), management (18\%), and least related to governance $(5 \%)$, visitors $(4 \%)$, waste $(3 \%)$, and ecosystem services (2\%). The number of codes in each category with major subcategories are shown in Table 3.

Think about a green area that you know or frequent. To what extent are you satisfied with the following aspects?

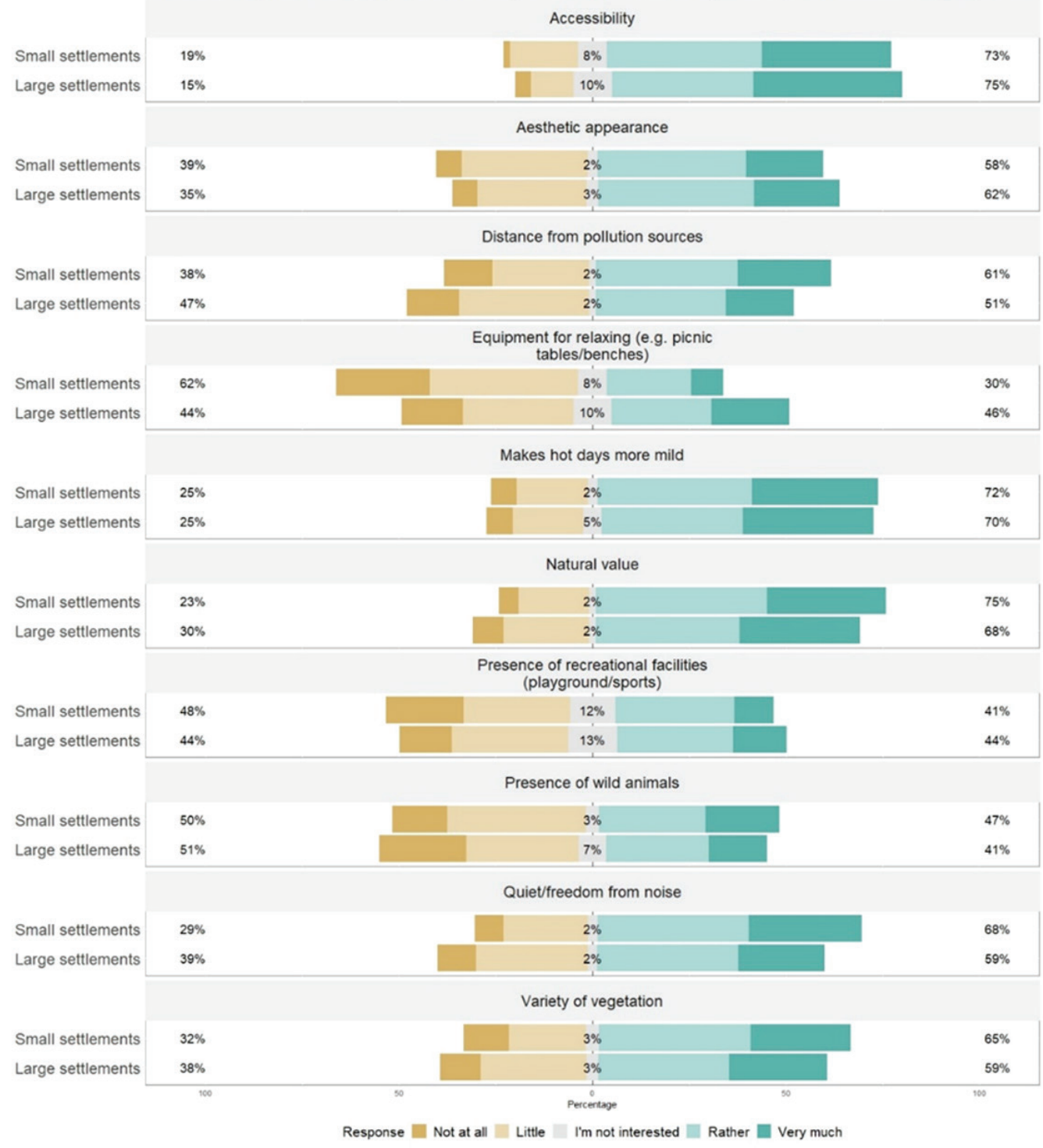

Figure 3. Satisfaction with different elements of green spaces the respondents know or frequent $(\mathrm{N}=460)$. 
Table 3. Categories and frequencies of codes given in the analysis of the open-ended question.

\begin{tabular}{|c|c|c|c|}
\hline Category & $\mathrm{N}$ of codes & Subcategories & $\%$ of codes \\
\hline \multirow{5}{*}{ Urban planning } & \multirow{5}{*}{140} & More green spaces & 36 \\
\hline & & Lack of green spaces & 26 \\
\hline & & Better planning & 11 \\
\hline & & Construction & 11 \\
\hline & & Other & 16 \\
\hline \multirow{5}{*}{ Design } & \multirow{5}{*}{107} & Equipment & 26 \\
\hline & & Trees & 22 \\
\hline & & Naturalness & 13 \\
\hline & & Landscaping & 7 \\
\hline & & Other & 32 \\
\hline \multirow{4}{*}{ Management } & \multirow{4}{*}{101} & Maintenance & 61 \\
\hline & & Tree management & 12 \\
\hline & & Bad management practice & 12 \\
\hline & & Other & 14 \\
\hline \multirow{3}{*}{ Governance } & \multirow{3}{*}{26} & Better governance & 39 \\
\hline & & Participation & 23 \\
\hline & & Other & 38 \\
\hline \multirow{3}{*}{ Visitors } & \multirow{3}{*}{19} & Behavior & 69 \\
\hline & & Visitor control & 26 \\
\hline & & Information & 5 \\
\hline \multirow{4}{*}{ Waste } & \multirow{4}{*}{16} & Illegal waste disposal & 38 \\
\hline & & A lot of waste & 31 \\
\hline & & Recycling & 25 \\
\hline & & Less waste & 6 \\
\hline \multirow{4}{*}{ Ecosystem services } & \multirow{4}{*}{12} & Thermoregulation & 42 \\
\hline & & Wellbeing & 33 \\
\hline & & Education & 17 \\
\hline & & Other & 8 \\
\hline \multirow{2}{*}{ Without suggestion } & \multirow{2}{*}{133} & Did not share anything & 74 \\
\hline & & Satisfied & 26 \\
\hline
\end{tabular}

\section{DISCUSSION}

This study is the first survey of the perceptions and attitudes towards green spaces in Croatia on a large spatial scale, covering cities and rural areas across the country. The survey was disseminated through the researchers' social networks, mailing lists and social media. Even though the sample of the respondents was purposive and small, and therefore not representative of the whole country, the results are exploratory in nature and important. This questionnaire was able to reach respondents from 64 different locations in Croatia (data not shown), thus achieving the first goal of the survey, which was to collect comprehensive data. The significant overrepresentation of women (76.3\%) is the result of the personal interest and motivation to participate in the survey by the people contacted and reached via social media, similar to other surveys on the use of and attitudes towards green spaces during the COVID-19 pandemic (da Schio et al. 2020). Based on Croatian census data, there is $51.7 \%$ of females in the general population, 
therefore generalization on gender is not possible in this case (Statistical yearbook of the Republic of Croatia, 2018). This paper presents the first exploratory study of people's perceptions and attitudes towards green spaces in Croatia at the country level. Similar to other studies (Grigoletto et al. 2021), this questionnaire included few young people, i.e. under 20 years old, but $17 \%$ of the respondents were in the category of 20-29 years old. As younger people are usually difficult to reach in this type of research, it could be argued that this is related to the lockdown period and the distribution of the questionnaire through social networks, among other factors. Based on data collected in a similar period, people in Croatia reported spending more time looking at screens than usual (Pišot et al. 2020), which could contribute to a higher proportion of younger people and a higher likelihood of participating in the study. On the other hand, schools in Croatia switched to online instruction during the period when data for this study were collected. Therefore, it could be assumed that potential respondents younger than 20 years felt overwhelmed with online classes and were oversaturated with time spent in front of screens for educational purposes, so they were less keen to invest their time for socially and environmentally useful purposes such as our survey. Besides pressing issues of a new type of education, another assumption is that people younger than 20 years are not interested in participating because they do not recognize urban green spaces as personally important, attractive or significant enough, which may explain to some extent the low percentage of the younger people in the sample. In general, the main respondents to the questionnaire were people aged between 30 and 49 years, which is around the average (43.4) in Croatia (Statistical Yearbook of the Republic of Croatia 2018). Although sociodemographic characteristics might have an impact on perceptions and attitudes, these relationships were not examined in this study. However, the differences in attitudes and perceptions of respondents from differently sized settlements were examined. It was hypothesised that there will be differences in attitudes and perceptions towards green spaces in differently sized settlements in Croatia. It was hypothesised that different experiences of nature will shape attitudes and perceptions (Berenguer et al. 2005), but also that perceptions of the environment of green spaces may have an impact on community connectedness, which could promote participation in green space issues (Arnberger and Eder 2012). Given the low to non-existent public participation in green space issues in Croatia, research on the perceptions of green spaces in settlements of different sizes could improve the understanding of the relationship between people and nature and enable better decision-making adapted to community needs.

First, respondents' attitudes toward the benefits of green space were examined. The vast majority of the respondents agreed with the proposed statements about the various benefits of green spaces. Statistically significant differences in the perception of the benefits of green spaces depending on the size of the settlements the respondents come from were not found. This result is consistent with similar research on attitudes towards environmental issues, where no difference was found between urban and rural areas, as concern for the environment was high among residents of both areas (Berenguer et al. 2005). There was also a generally positive attitude towards the benefits of green spaces in our sample.

The second set of Likert scale questions revealed that people have similar perceptions about the management and possible negative impacts. However, this information is important for urban planning as it provides data on the perceived negative aspects of green spaces and their management, which could have consequences for human well-being as well as additional costs for maintenance in the most confined urban environments (von Döhren and Haase 2019). Interviewees from the different large housing estates agreed that trees are an environmental value worth spending money on and that green spaces are an important part of the landscape that needs to be considered during construction. Potential negative impacts of trees were not perceived as such by the respondents. However, statistically significant differences were found between two groups of respondents for two groups of statements. Based on the assumption that people in smaller settlements tend to have a private garden to, they perceive its management as a cost to the household, which may explain why people from smaller settlements reported higher levels of agreement with this issue. As smaller settlements have smaller budgets than larger ones, a possible lack of experts in tree and green space maintenance could also lead to trees being perceived as dangerous. Systematic education in smaller settlements about trees and tree management could improve this negative perception of people. Education is an important resource in green space planning and management (Fischer et al. 2020).

To further develop research on different perceptions and attitudes towards green spaces, it was decided to use another set of questions and investigate possible differences. Further analysis identified differences in perceptions between people from differently sized settlements. This is related to the importance of private or public green spaces and the elements of green spaces they feel could be improved. This suggests that people have similar attitudes but slightly different perceptions of green spaces concerning environmental conditions.

Although people agree with the statements that green spaces are important, that they provide social benefits and are a human right for all citizens, on the other hand, many of the respondents in this survey were not completely satisfied with the benefits that green spaces provide in their neighbourhood. Similar results were found for Zagreb in the study by Krajter Ostoić et al. (2017), where people expressed high importance of urban green spaces and lower satisfaction with their maintenance and management. When asked how satisfied they were with the aspects of known or frequently used green spaces, overall the respondents were slightly more satisfied than dissatisfied; however, there is room for improvement in green spaces in both environments. It must be acknowledged that the respondents were not asked to define the green spaces they were referring to, but researchers took these results to show overall satisfaction, so this is an important finding for green space management, regardless of the size of settlements or the type of green space. In terms of differences in perceptions, it was found that residents of smaller settlements were more dissatisfied 
with equipment than the respondents from large settlements. Again, a possible explanation could be lower financial resources available for the management of green spaces to provide more equipment.

As mentioned earlier, the data for this study were collected using an international questionnaire. The results and the comparison between countries regarding the use, visitation and perception of green spaces during the first closure period due to COVID-19 can be found in Ugolini et al. (2020). As for the answers to the open questions, they were also reported in the mentioned study, but over a whole sample, while in our study we analysed only the Croatian sample. The different techniques used in the two studies (text mining and coding, respectively) have led to a slightly different presentation of the results, but the main conclusions remain the same. Another important difference between the results is the depth of coding undertaken in the two analyses. While Ugolini et al. use the entire sample collected (including the Croatian one), here we only present the analysis of the entire Croatian sample, which is thus more detailed.

Urban planning is also the most prominent category in our presentation of results, which expresses the reliability of the coding results. The majority of respondents indicated that more green spaces are needed, which highlights the important issue of urbanisation and building development. Croatia as a post-socialist country faces similar problems as described in Kronenberg et al. (2020). The problem of changing land use and the expressed concern about new development are understandable, as the literature provides examples of the loss of large amounts of green spaces due to new development (lojă et al. 2011). However, the provision of new green spaces, particularly in medium-sized cities, is often influenced by several factors that affect the supply of new green spaces (Boulton et al. 2020).

Insight into the type of green spaces Croatian residents would like to see was provided through proposals coded as designs. The information collected provides a good opportunity to better understand the residents' perceptions and needs, which enables designers and managers to design and redesign green spaces according to the needs of actual users. Respondents expressed a desire for more equipment in green spaces, particularly trees and more biodiversity, naturalness and edible fruit trees in green spaces. Research has shown that people have a very good subjective sense of the level of biodiversity in their urban environment (Gunnarsson et al. 2017). Therefore, those who indicated in the open-ended question that they would like to see more naturalness should be considered. Research also shows that people are generally positive about biodiversity-friendly green space management (Fischer et al. 2020).

Management was the third most frequently mentioned category among the respondents. They expressed an overarching need for better management, while also emphasising that they perceive poor management practices in their neighbourhoods. A recent study with citizens of the city of Zagreb concluded that the residents were more concerned about management practices related to green spaces than the physical component of these areas (Krajter Ostoić et al. 2017). Therefore, management practices that are most easily perceived by visitors and users should take into account their perceptions. This could lead to an improvement in management practices and overall user satisfaction.

Recent examples from Italy have shown how local policies and their programmes can improve the setting and use of urban green spaces (Grigoletto et al. 2021). Therefore, policy and management are important factors in creating not only better green spaces, but also better attitudes towards them among citizens. As urban green spaces are at the heart of a sustainable future, local authorities need to plan green spaces in collaboration with the citizens who will use them most. Public participation is also emphasised by respondents in their consideration of green spaces. Therefore, this result is important for the local context and shows that people need to be more involved in the planning and management of green spaces.

Although the perceived amount of litter, illegal littering, irresponsible visitor behaviour, visitor control and poor behaviour of other users were less frequently cited, these dissatisfactions can have a significant impact on the quality of time spent in green spaces (Ciesielski and Stereńczak 2018). Problems related to litter such as illegal littering or lack of bins, the need for additional equipment essential for spending time in green spaces, and dissatisfaction with the behaviour of other users of green spaces were frequently expressed as problems in a recent survey of visitors in one of Zagreb's forest parks (Krajter Ostoić et al. 2017, Kičić et al. 2020). Research has shown that even a moderate amount of litter can elicit a reaction from green space users (Verlič et al. 2015). In addition, the majority of respondents indicated that they prioritise waste management at their respective residences. Litter affects the aesthetic appearance of green spaces and detracts from the overall experience of contaminated spaces and the services they provide. Therefore, it can be concluded that waste is a problem that needs to be worked on, regardless of the population or size of the settlement in Croatia. The respondents focused more on negative experiences and changes they would like to see in green spaces. Positive impacts on well-being and satisfaction with various ecosystem services were therefore the least mentioned problems.

\section{CONCLUSIONS}

Although it was hypothesised that there would be differences in the perceptions and attitudes of respondents from differently sized settlements in Croatia, more similarities than differences were found. This means that people generally have similar attitudes towards green spaces, regardless of the size of the municipality. The differences were related to the aspects of local management rather than to general attitudes towards green spaces as such. Beneficial attitudes towards green spaces have been described in the literature, but in densely built-up areas in Asia (Lo and Jim 2012). In the Croatian context, utilitarian attitudes and dissatisfaction in smaller settlements are most likely the results of uneven funding allocated to green space management than in large settlements. Since attitudes and perceptions are influenced by numerous factors, including the respondents' sociodemographic characteristics, it must 
be acknowledged that these interactions were not assessed in this study and may explain some of the differences. However, since this is an explanatory study, it is difficult to generalize the results. However, it should be emphasized that the results make a valuable contribution to the academic literature that explores differences in perceptions in the relationship between people and green spaces. The research contributes to a better understanding of the relationship between people and green spaces, especially regarding the different perceptions and needs of residents of different settlements. The results could be used to inform green space management in smaller settlements in Croatia, as well as in large settlements, about the aspects of their work which could be improved according to the needs of actual users.

\section{Author Contributions}

Conceptualization: AMM, MK, DV and SKO; methodology: AMM, MK, DV and SKO; software: MK; validation: AMM, MK, DV and SKO; formal analysis: MK; investigation: $A M M$; data curation: MK; writing - original draft preparation: AMM, MK, DV and SKO; writing - review and editing: $\mathrm{AMM}, \mathrm{MK}, \mathrm{DV}$ and SKO; visualization: $\mathrm{MK}, \mathrm{AMM}$; super-vision: DV and SKO; project administration: SKO; funding acquisition: SKO. All authors have read and agreed to the published version of the manuscript.

\section{Funding}

Work of Silvija Krajter Ostoić, Martina Kičić and Ana Marija Marin was supported by the project "Improving Green Infrastructure Planning and Management through Participatory Mapping of Cultural Ecosystem Services" (CULTUR-ES) funded by Croatian Science Foundation (project number UIP-2017-05-1986). Work of Ana Marija Marin was additionally supported by project "Young Researchers' Career Development Project-Training New Doctoral Students" (project number DOK-2020-01-6490) funded by Croatian Science Foundation.

\section{Acknowledgments}

The authors would like to thank those who participated in the survey. Without their time and effort the research would not be possible.

\section{Conflicts of Interest}

The authors declare no conflict of interest.

\section{REFERENCES}

Arnberger A, Eder R, 2012. The Influence of Green Space on Community Attachment of Urban and Suburban Residents. Urban For Urban Gree 11(1): 41-49. https://doi.org/10.1016/i. ufug.2011.11.003.

Baur JWR, Tynon JF, Gómez E, 2013. Attitudes about Urban Nature Parks: A Case Study of Users and Nonusers in Portland, Oregon. Landscape Urban Plan 117: 100-111. https://doi.org/10.1016/i. landurbplan.2013.04.015.

Berenguer J, Corraliza JA, Martín R, 2005. Rural-Urban Differences in Environmental Concern, Attitudes, and Actions. Eur J Psychol Assess 21(2): 128-38. https://doi.org/10.1027/10155759.21.2.128.

Boulton C, Dedekorkut-Howes A, Holden M, Byrne J, 2020. Under Pressure: Factors Shaping Urban Greenspace Provision in a Mid-Sized City. Cities 106: 102816. https://doi.org/10.1016/i. cities.2020.102816.

Buchel S, Frantzeskaki N, 2015. Citizens' Voice: A Case Study about Perceived Ecosystem Services by Urban Park Users in Rotterdam, the Netherlands. Ecosyst Serv 12: 169-77. https://doi. org/10.1016/i.ecoser.2014.11.014.

Ciesielski M, Stereńczak K, 2018. What Do We Expect from Forests? The European View of Public Demands. J Environ Manage 209: 139-51. https://doi.org/10.1016/j.jenvman.2017.12.032.

Derks J, Giessen L, Winkel G, 2020. COVID-19-Induced Visitor Boom Reveals the Importance of Forests as Critical Infrastructure. Forest Policy Econ 118: 102253. https://doi.org/10.1016/i. forpol.2020.102253.

von Döhren P, Haase D, 2019. Risk Assessment Concerning Urban Ecosystem Disservices: The Example of Street Trees in Berlin, Germany. Ecosyst Serv 40: 101031. https://doi.org/10.1016/i. ecoser.2019.101031.
Fischer LK, Neuenkamp L, Lampinen J, Tuomi M, Alday JG, Bucharova A, Cancellieri L, Casado-Arzuag, I, Čeplová N, Cerveró L, Deák B, Eriksson $\mathrm{O}$, Fellowes MDE, Fernández de Manuel B, Filibeck G, González-Guzmán A, Hinojosa MB, Kowarik I, Lumbierres B, Miguel A, Pardo R, Pons X, Rodríguez-García E, Schröder R, Sperandii MG, Unterweger P, Valkó O, Vázquez V, Klaus VH, 2020. Public Attitudes toward Biodiversity-Friendly Greenspace Management in Europe. Conserv Lett 13(4): e12718. https://doi.org/10.1111/conl.12718.

Grigoletto A, Mauro M, Campa F, Loi A, Zambon MC, Bettocchi M, Nieuwenhuijsen M, Bragonzoni L, Maietta Latessa P, Toselli S, 2021. Attitudes towards Green Urban Space: A Case Study of Two Italian Regions. Int J Env Res Pub He 18(12): 6442. https://doi. org/10.3390/ijerph18126442.

Gunnarsson B, Knez I, Hedblom M, Sang ÅO, 2017. Effects of Biodiversity and Environment-Related Attitude on Perception of Urban Green Space. Urban Ecosyst 20(1): 37-49. https://doi. org/10.1007/s11252-016-0581-x.

Haase $D$, Larondelle $N$, Andersson E, Artmann M, Borgström S, Breuste J, Gomez-Baggethun E, Gren Å, Hamstead Z, Hansen R, Kabisch N, Kremer P, Langemeyer J, Rall EL, McPhearson T, Pauleit S, Qureshi S, Schwarz N, Voigt A, Wurster D, Elmqvist T, 2014. A Quantitative Review of Urban Ecosystem Service Assessments: Concepts, Models, and Implementation. AMBIO 43(4): 413-33. https://doi.org/10.1007/s13280-014-0504-0.

Iojă Cl, Rozylowicz L, Pătroescu M, Niţă MR, Vânau GO, 2011. Dog Walkers' vs. Other Park Visitors' Perceptions: The Importance of Planning Sustainable Urban Parks in Bucharest, Romania. Landscape Urban Plan 103(1): 74-82. https://doi.org/10.1016/i. landurbplan.2011.06.002.

Kičić M, Marin AM, Vuletić D, Kaliger I, Matošević N, Šimpraga S, Krajter Ostoić S, 2020. Who Are the Visitors of Forest Park Grmoscica and What Are Their Needs? Results of Quantitative Exploratory Survey. South-east Eur for 11(2): 169-80. https://doi. org/10.15177/seefor.20-19. 
Kleinschroth F, Kowarik I, 2020. COVID-19 Crisis Demonstrates the Urgent Need for Urban Greenspaces. Front Ecol Environ 18(6): 318-319. https://doi.org/10.1002/fee.2230.

Krajter Ostoić S, Konijnendijk van den Bosch CC, Vuletić D, Stevanov M, Živojinović I, Mutabdžija-Bećirović S, Lazarević J, Stojanova B, Blagojević D, Stojanovska M, Nevenić R, Pezdevšek Malovrh $\breve{S}$, 2017. Citizens' Perception of and Satisfaction with Urban Forests and Green Space: Results from Selected Southeast European Cities. Urban For Urban Gree 23: 93-103. https://doi. org/10.1016/i.ufug.2017.02.005.

Krajter Ostoić S, Vuletić D, Planinšek Š, Vilhar U, Japelj A, 2020a. Three Decades of Urban Forest and Green Space Research and Practice in Croatia and Slovenia. Forests 11(2): 136. https://doi. org/10.3390/f11020136.

Krajter Ostoić S, Marin AM, Kičić M, Vuletić D, 2020b. Qualitative Exploration of Perception and Use of Cultural Ecosystem Services from Tree-Based Urban Green Space in the City of Zagreb (Croatia). Forests 11(8): 876. https://doi.org/10.3390/f11080876.

Kronenberg J, Haase A, Łaszkiewicz E; Antal A, Baravikova A, Biernacka $M$, Dushkova D, Filčak R, Haase D, Ignatieva M, Khmara Y, Niţă MR, Onose DA, 2020. Environmental Justice in the Context of Urban Green Space Availability, Accessibility, and Attractiveness in Postsocialist Cities. Cities 106: 102862. https://doi.org/10.1016/i. cities.2020.102862.

Larondelle N, Haase D, 2017. Back to Nature! Or Not? Urban Dwellers and Their Forest in Berlin. Urban Ecosyst 20(5): 1069-1079. https://doi.org/10.1007/s11252-017-0660-7.

Lo $\mathrm{AYH}$, Jim CY, 2012. Citizen Attitude and Expectation towards Greenspace Provision in Compact Urban Milieu. Land Use Policy 29(3): 577-586. https://doi.org/10.1016/i. landusepol.2011.09.011.

Maraja R, Barkmann J, Tscharntke T, 2016. Perceptions of Cultural Ecosystem Services from Urban Green. Ecosyst Serv 17: 33-39. https://doi.org/10.1016/i.ecoser.2015.11.007.

Mathey J, Arndt T, Banse J, Rink D, 2018. Public Perception of Spontaneous Vegetation on Brownfields in Urban Areas-Results from Surveys in Dresden and Leipzig (Germany). Urban For Urban Gree 29: 384-392. https://doi.org/10.1016/i.ufug.2016.10.007.

Morse JW, Gladkikh TM, Hackenburg DM, Gould RK, 2020. COVID-19 and Human-Nature Relationships: Vermonters' Activities in Nature and Associated Nonmaterial Values during the Pandemic. PLOS ONE 15(12): e0243697. https://doi.org/10.1371/journal. pone.0243697. da Schio N, Phillips A, Fransen K, Wolff M. Haase D, Ostoić SK, Živojinović I, Vuletić D, Derks J, Davies C, Lafortezza R, Roitsch D, Winkel G, De Vreese R, 2021. The Impact of the COVID-19 Pandemic on the Use of and Attitudes towards Urban Forests and Green Spaces: Exploring the Instigators of Change in Belgium. Urban For Urban Gree 65: 127305. https://doi.org/10.1016/i. ufug.2021.127305.

Pišot S, Milovanović I, Šimunič B, Gentile A, Bosnar K, Prot F, Bianco A, Lo Coco G, Bartoluci S, Katović D. Bakalár P, Kovalik Slančová T, Tlučáková L, Casals C, Feka K, Christogianni A, Drid P, 2020. Maintaining Everyday Life Praxis in the Time of COVID-19 Pandemic Measures (ELP-COVID-19 Survey). Eur J Public He 30(6): 1181-1186. doi: https://doi.org/10.1093/eurpub/ckaa157.

Poortinga W, Bird N, Hallingberg B, Phillips R, Williams D, 2021. The Role of Perceived Public and Private Green Space in Subjective Health and Wellbeing during and after the First Peak of the COVID-19 Outbreak. Landscape Urban Plan 211: 104092. https:// doi.org/10.1016/i.landurbplan.2021.104092.

Pouso S, Borja Á, Fleming LE, Gómez-Baggethun E, White MP, Uyarra MC, 2021. Contact with Blue-Green Spaces during the COVID-19 Pandemic Lockdown Beneficial for Mental Health. Science of The Total Environment 756: 143984. https://doi.org/10.1016/i. scitotenv.2020.143984.

Reed MS, 2008. Stakeholder Participation for Environmental Management: A Literature Review. Biol Conserv 141(10): 24172431. https://doi.org/10.1016/i.biocon.2008.07.014.

Statistical Yearbook of the Republic of Croatia. 2018. ISSN 1333-3305

Swanwick C, 2009. Society's Attitudes to and Preferences for Land and Landscape. Land Use Policy 26: 62-75. https://doi.org/10.1016/i. landusepol.2009.08.025.

Ugolini F, Massetti L, Calaza-Martínez P, Cariñanos P, Dobbs C, Krajter Ostoić S, Marin AM, Pearlmutter D, Saaroni H, Šaulienè I. Simoneti M, Verlič A, Vuletić D, Sanesik G, 2020. Effects of the COVID-19 Pandemic on the Use and Perceptions of Urban Green Space: An International Exploratory Study. Urban For Urban Gree 56: 126888. https://doi.org/10.1016/i.ufug.2020.126888.

Venter ZS, Barton DN, Gundersen V, Figari H, Nowell M, 2020. Urban Nature in a Time of Crisis: Recreational Use of Green Space Increases during the COVID-19 Outbreak in Oslo, Norway. Environmental Res Lett 15(10): 104075. https://doi. org/10.1088/1748-9326/abb396.

Verlič A, Arnberger A, Japelj A, Simončič P, Pirnat J, 2015. Perceptions of Recreational Trail Impacts on an Urban Forest Walk: A Controlled Field Experiment. Urban For Urban Gree 14(1): 89-98. https://doi.org/10.1016/i.ufug.2014.12.004. 